\title{
A gene-protein assay for human epidermal growth factor receptor 2 (HER2): brightfield tricolor visualization of HER2 protein, the HER2 gene, and chromosome 17 centromere (CEN17) in formalin-fixed, paraffin-embedded breast cancer tissue sections
}

Hiroaki Nitta ${ }^{1 *}$, Brian D. Kelly ${ }^{2}$, Mary Padilla ${ }^{3}$, Nikolaus Wick ${ }^{4}$, Patrick Brunhoeber ${ }^{5}$, Isaac Bai ${ }^{6}$, Shalini Singh ${ }^{5}$, Jim Ranger-Moore ${ }^{6}$, Chris Bieniarz ${ }^{2}$, Hitoshi Tsuda ${ }^{7}$ and Thomas M Grogan ${ }^{1}$

\begin{abstract}
Background: The eligibility of breast cancer patients for human epidermal growth factor receptor 2 (HER2)-directed therapies is determined by the HER2 gene amplification and/or HER2 protein overexpression status of the breast tumor as determined by in situ hybridization (ISH) or immunohistochemistry $(\mathrm{IHC})$, respectively. Our objective was to combine the US Food and Drug Administration (FDA)-approved HER2 \& chromosome 17 centromere (CEN17) brightfield ISH (BISH) and HER2 IHC assays into a single automated HER2 gene-protein assay allowing simultaneous detection of all three targets in a single tissue section.

Methods: The HER2 gene-protein assay was optimized using formalin-fixed, paraffin-embedded (FFPE) samples of the xenograft tumors MCF7 [HER2 negative (non-amplified gene, protein negative)] and Calu-3 [HER2 positive (amplified gene, protein positive)]. HER2 IHC was performed using a rabbit monoclonal anti-HER2 antibody (clone $4 B 5$ ) and a conventional 3,3'-diaminobenzidine IHC detection. The HER2 \& CEN17 BISH signals were visualized using horseradish peroxidase-based silver and alkaline phosphatase-based red detection systems, respectively with a cocktail of 2,4-dinitrophenyl-labeled HER2 and digoxigenin-labeled CEN17 probes. The performance of the gene-protein assay on tissue microarray slides containing 189 randomly selected FFPE clinical breast cancer tissue cores was compared to that of the separate HER2 IHC and HER2 \& CEN17 BISH assays.

Results: HER2 protein detection was optimal when the HER2 IHC protocol was used before (rather than after) the BISH protocol. The sequential use of HER2 IHC and HER2 \& CEN17 BISH detection steps on FFPE xenograft tumor sections appropriately co-localized the HER2 protein, HER2 gene, and CEN17 signals after mitigating the silver background staining by using a naphthol phosphate-containing hybridization buffer for the hybridization step. The HER2 protein and HER2 gene status obtained using the multiplex HER2 gene-protein assay demonstrated high concordance with those obtained using the separate HER2 IHC and HER2 \& CEN17 BISH assays, respectively.

Conclusions: We have developed a protocol that allows simultaneous visualization of the HER2 IHC and HER2 \& CEN17 BISH targets. This automated protocol facilitated the determination of HER2 protein and HER2 gene status in randomly selected breast cancer samples, particularly in cases that were equivocal or exhibited tumor (Continued on next page)
\end{abstract}

\footnotetext{
*Correspondence: hiro.nitta@ventana.roche.com

'Medical Innovation, Ventana Medical Systems, Inc., Tucson, AZ, USA

Full list of author information is available at the end of the article
} 


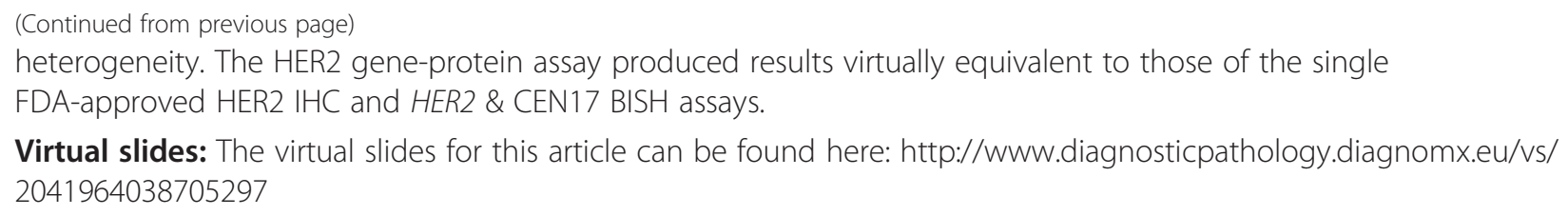

Keywords: Gene-protein assay, Dual color in situ hybridization, Immunohistochemistry, HER2, Breast cancer

\section{Background}

Breast cancer is the most common cause of cancer death in Europe and the second leading cause of cancer death in the United States. The oncogene HER2, which encodes human epidermal growth factor receptor 2 (HER2) protein, is amplified in $20-30 \%$ of breast cancer cases [1] and is the target of HER2-directed anti-cancer therapies. Trastuzumab (Herceptin; Genentech, South San Francisco, CA, USA), a humanized monoclonal anti-HER2 antibody, has therapeutic effects against HER2 gene and/or HER2 protein positive breast cancers as an adjuvant therapy. The small molecule dually targeted drug Lapatinib (Tyverb/Tykerb; GlaxoSmithKline, London, United Kingdom), which inhibits the tyrosine kinase activities of the HER2 and of epidermal growth factor receptor (EGFR) proteins, is a first-line therapeutic agent against triple positive breast cancers (positive for HER2 protein, estrogen receptor, and progesterone receptor) and it is also used in treating breast cancers refractory to trastuzumab therapy. Several drugs are currently in Phase III clinical trials for treatment of HER2 positive breast cancer, including pertuzumab, neratinib, and afatinib.

The American Society of Clinical Oncology (ASCO) and the College of American Pathologists (CAP) have introduced guidelines for HER2 status assessments based on the level of HER2 protein overexpression determined by immunohistochemistry (IHC) and on the level of HER2 gene amplification determined by in situ hybridization (ISH) on formalin-fixed, paraffin-embedded (FFPE) breast cancer tissue sections [2]. However, which of the two methods is superior for assessing the HER2 status of breast cancer patients is unclear.

The two HER2 IHC-based diagnostic tests for assessing HER2 protein expression that are approved by the US Food and Drug Administration (FDA) use either a rabbit polyclonal (DAKO, Glostrup, Denmark) or a rabbit monoclonal (Ventana Medical Systems, Inc., Tucson, AZ, USA) antibody against HER2 protein. The results of these tests are scored semi-quantitatively as either 0 (negative), $1+$ (negative), 2+ (equivocal), or 3+ (positive) [2]. The four FDA-approved ISH diagnostic tests for quantifying HER2 gene copy numbers are dual color fluorescence ISH (FISH) (Abbott Molecular, Illinois, USA), single color chromogenic ISH (CISH) (Invitrogen, California, USA), dual color brightfield in situ hybridization (BISH) (Ventana), and dual color CISH (Dako) assays. For the dual color assays, results are determined as the ratio of the $H E R 2$ gene signal to the chromosome 17 centromere (CEN17) signal (negative: HER 2/CEN17 < 1.8; equivocal: $1.8 \leq H E R 2 / C E N 17 \leq 2.2$; positive: HER2/CEN17> 2.2) [2]. The results of single color ISH assays are considered positive if they detect six or more HER2 gene copies and negative if they detect fewer than six [3].

HER2 gene status and HER2 protein expression are generally concordant in breast cancer [4]. However, discordance between HER2 IHC and HER2 ISH assay results can be caused by various factors and is not uncommon. For example, variations in tissue processing protocols affect HER2 protein detection more than the HER2 gene detection; thus ISH assays can be more accurate than IHC assays when the pre-analytical process is not standardized [4]. Tumor heterogeneity can also contribute to discordance between HER2 IHC and HER2 ISH scoring [5]. The possibility that a breast cancer patient will receive an incorrect HER2 status assessment is decreased when both assays are used, particularly when the cases are equivocal [6].

The simultaneous brightfield detection of HER2 protein and HER2 gene expression "HER2 gene-protein assay" in FFPE breast cancer tissue sections has been previously reported by three independent groups [7-9]. First, DownsKelly et al. [7] successfully combined an alkaline phosphatase (AP)-based fast red dye system for HER2 IHC with a horseradish peroxidase (HRP)-based silver deposition system for HER2 ISH. Then, Ni et al. [8] combined a fast red dye system for HER2 IHC with an HRP-based 3,3'-diaminobenzidine (DAB) system for HER2 ISH. In the most recent report of a HER2 gene-protein assay, Reisenbichler et al. [9] used DAB-based detection for both HER2 IHC and HER2 ISH in a single color HER2 geneprotein assay. Co-localization of CEN17 was not included in any of these HER2 gene-protein assays, even though using the copy numbers of both the HER2 gene and CEN17 is considered optimal in determining HER2 gene status for possible anti-HER2 therapies [4]. Furthermore, the previously described HER2 gene-protein assays were performed with semi-automated protocols requiring some manual steps.

In this study, our objectives were: 1) to develop an automated HER2 gene-protein assay for simultaneous tricolor visualization of HER2 protein, the HER2 gene, 
and CEN17 in FFPE xenograft tumors and clinical breast cancer cases and 2) to evaluate the performance of this assay in determining the HER2 status of clinical breast cancer tissues on tissue microarray (TMA) slides.

\section{Methods}

\section{Tissue samples}

FFPE MCF7 and Calu-3 xenograft tumors were used for the initial development and optimization of the HER2 gene-protein assay. MCF7 is a breast adenocarcinoma cell line in which the HER2 gene is not amplified (average copy number $=2$ ) and Calu-3 is a lung adenocarcinoma cell line in which HER2 is amplified (average copy number $=30)$ [10]. Paraffin sections of the tumors were placed onto Superfrost Plus glass slides (Erie Scientific Company, Portsmouth, NH, USA) for analysis.

The performance of the HER2 gene-protein assay was examined using 189 breast cancer tissue cores on TMA slide sets provided by the National Cancer Center Hospital $(\mathrm{NCCH})$, Tokyo, Japan. The breast cancer tissue samples were randomly selected from a tissue archive of samples acquired between 1991 and 1995. The protocol was approved by the NCCH Institutional Review Board. The TMA slides contained 36-41 tissue cores on a Matsunami Platinum coated glass slide (Matsunami Glass Ind., Ltd., Osaka, Japan). To orient the tissue cores and provide a positive control, two tissue cores from a selected HER2-amplified breast cancer case were included in each TMA block. The adhesion of the tissue cores onto the TMA slides was enhanced by baking the slides for $15 \mathrm{~min}$ at $65^{\circ} \mathrm{C}$ before each assay.

\section{IHC determination of HER2 protein expression}

The FDA-approved HER2 IHC assay using PATHWAY HER-2/neu rabbit monoclonal antibody (clone 4B5; Ventana) was performed with $i$ View DAB Detection Kit (Ventana) on a BenchMark XT automated staining system (Ventana). Briefly, the tissue sections were deparaffinized with EZ Prep (Ventana) at $75^{\circ} \mathrm{C}$, heat pretreated in Cell Conditioning 1 (CC1; Ventana) using "standard cell conditioning" for antigen retrieval at $100^{\circ} \mathrm{C}$, and then incubated with the anti-HER2 primary antibody for $32 \mathrm{~min}$ at $37^{\circ} \mathrm{C}$ after inactivation of the endogenous peroxidase with hydrogen peroxide for $4 \mathrm{~min}$. They were then blocked using Endogenous Biotin Blocking Kit (Ventana), incubated with a biotinylated secondary antibody for $8 \mathrm{~min}$, and incubated with a streptavidin-HRP conjugate for $8 \mathrm{~min}$ at $37^{\circ} \mathrm{C}$. The immunolocalized HER2 protein was visualized using a copper-enhanced DAB reaction. The slides were counterstained with Hematoxylin II (Ventana) for $4 \mathrm{~min}$ and Bluing Reagent (Ventana) for $4 \mathrm{~min}$ and coverslips were applied by an automated coverslipper (TissueTek Film Automated Coverslipper; Sakura Finetek Japan, Tokyo, Japan).

\section{Dual color BISH determination of HER2/CEN17 ratio}

The FDA-approved dual color BISH assay (INFORM HER2 Dual ISH DNA Probe Assay; Ventana) for HER2 and CEN17 quantitation was also performed on the BenchMark XT using HER2 and CEN17 probes labeled with 2,4dinitrophenyl (DNP) and digoxigenin (DIG), respectively. Briefly, after the tissue cores were deparaffinized with EZ Prep at $75^{\circ} \mathrm{C}$, they were subjected to three 12 min cycles of heat pretreatment at $90^{\circ} \mathrm{C}$ in EZ Prep-diluted Cell Conditioning 2 (CC2; Ventana) followed by protease digestion with ISH Protease 3 (Ventana) for $16 \mathrm{~min}$ at $37^{\circ} \mathrm{C}$. The genomic DNA in tissue sections and the nick-translated HER 2 and CEN17 probes were co-denatured by heat treatment for $20 \mathrm{~min}$ at $80^{\circ} \mathrm{C}$ followed by a hybridization step for $6 \mathrm{~h}$ at $44^{\circ} \mathrm{C}$. After three $8 \mathrm{~min}$ stringency washes were carried out in $2 \times \operatorname{SSC}$ (Ventana) at $72^{\circ} \mathrm{C}$, the HER2 and CEN17 signals were detected using ultraView SISH DNP and ultraView Red ISH DIG Detection Kits (Ventana), respectively.

For HER2 gene detection, the slides were incubated with a rabbit anti-DNP antibody for 20 min and then with a HRP-conjugated goat anti-rabbit antibody for $16 \mathrm{~min}$ at $37^{\circ} \mathrm{C}$. The HER2 BISH signal was detected as metallic silver deposits with silver acetate, hydroquinone, and hydrogen peroxide for $4 \mathrm{~min}$ at $37^{\circ} \mathrm{C}$. For CEN17 detection, the slides were incubated with a mouse anti-DIG antibody for 20 min and then with an AP-conjugated goat anti-mouse antibody for $32 \mathrm{~min}$ at $37^{\circ} \mathrm{C}$. The CEN17 BISH signal was developed as red dot staining with fast red and naphthol phosphate for $16 \mathrm{~min}$. Finally, the slides were counterstained with Hematoxylin II for $8 \mathrm{~min}$ and with Bluing Reagent for $4 \mathrm{~min}$. After the slides were rinsed and airdried, coverslips were applied by the Tissue-Tek Film Coverslipper.

\section{Development and optimization of the HER2 gene-protein assay}

The HER2 gene-protein assay was developed on the BenchMark XT using FFPE xenograft tumors and clinical breast cancer samples. The samples were stained under a variety of assay conditions to determine an optimum protocol needed to achieve HER2 protein, HER2 gene, and CEN17 staining results comparable to those of the individual HER2 IHC and HER2 \& CEN17 BISH assays. Optimum signal detection in the HER2 gene-protein assay was achieved by performing the IHC procedure before the $\mathrm{BISH}$ procedure. Reagent lots were consistent for all TMA slides across all assays and all assays were completed within one week.

The breast cancer TMA slides were subjected to the final optimized HER2 gene-protein staining protocol after the paraffin-embedded tissue cores were deparaffinized with a Liquid Coverslip (Ventana)-primed EZ Prep method. For HER2 protein staining, the TMA slides were 
heat pretreated with $\mathrm{CC} 1$ standard cell conditioning at $100^{\circ} \mathrm{C}$ and endogenous peroxidase was inactivated by incubation with hydrogen peroxide for $4 \mathrm{~min}$ at $37^{\circ} \mathrm{C}$. The tissue cores were incubated with the rabbit monoclonal anti-HER2 antibody for $32 \mathrm{~min}$ at $37^{\circ} \mathrm{C}$ and the endogenous biotin was blocked using Endogenous Biotin Blocking Kit. The slides were incubated with a biotinylated secondary antibody for $8 \mathrm{~min}$ and then with a HRP-conjugated streptavidin for $8 \mathrm{~min}$ at $37^{\circ} \mathrm{C}$. A copper enhanced DAB reaction was used to visualize the HER2 protein.

For HER2 gene \& CEN17 staining, the TMA slides were subjected to three 12 min cycles of heat pretreatment in EZ Prep-diluted $\mathrm{CC} 2$ at $90^{\circ} \mathrm{C}$ and then to mild tissue digestion with ISH Protease 3 for 16 min at $37^{\circ} \mathrm{C}$. The tissue samples were then hybridized with a cocktail of DNP-labeled HER2 and DIG-labeled CEN17 probes at $44^{\circ} \mathrm{C}$ for $6 \mathrm{~h}$ after denaturing for $4 \mathrm{~min}$ at $80^{\circ} \mathrm{C}$. HybClear blocking solution (Ventana), a hybridization buffer containing naphthol phosphate, was added to the probe cocktail to block the interaction between the DNP hapten on the HER2 probe and the DAB deposit during hybridization. Three $8 \mathrm{~min}$ stringency washes were carried out in $2 \times \mathrm{SSC}$ at $72^{\circ} \mathrm{C}$.

For HER2 gene detection, the tissue samples were incubated with a rabbit anti-DNP antibody for $20 \mathrm{~min}$ at $37^{\circ} \mathrm{C}$ followed by incubation with a HRP-conjugated goat anti-rabbit antibody for $24 \mathrm{~min}$ at $37^{\circ} \mathrm{C}$. HER2 BISH signal was developed for $8 \mathrm{~min}$ by the metallic silver deposit with silver acetate, hydroquinone, and hydrogen peroxide. For CEN17 detection, the slides were incubated with a mouse anti-DIG antibody for $20 \mathrm{~min}$ at $37^{\circ} \mathrm{C}$ followed by an AP-conjugated goat anti-mouse antibody incubation for $32 \mathrm{~min}$ at $37^{\circ} \mathrm{C}$. CEN17 BISH signal was developed with a fast red and naphthol phosphate mixture for $12 \mathrm{~min}$ at $37^{\circ} \mathrm{C}$. HER2 gene-protein slides were counterstained with Hematoxylin II for $8 \mathrm{~min}$ followed by Bluing Reagent for $4 \mathrm{~min}$ at $37^{\circ} \mathrm{C}$. Air-dried slides were coverslipped with the film coverslipper.

\section{Evaluation of HER2 gene-protein assay performance}

All tissue cores stained for the HER2 IHC, HER2 \& CEN17 BISH, and HER2 gene-protein assays were manually scored by three pathologists (MP, NW, PB). Two of the pathologists were experienced at scoring HER2 IHC and HER2 \& CEN17 BISH slides whereas the third was trained by reading the scoring guidelines immediately before scoring. In the HER2 IHC assay and HER2 gene-protein assay, tissue cores on TMA slides were scored for HER2 protein expression from 0 to $3+$. In the HER2 \& CEN17 BISH assay and the HER2 gene-protein assay, HER2 gene and CEN17 copy numbers were collected for calculating the ratio of $H E R 2 / C E N 17$ according to the scoring guideline.
All data analyses were conducted using SAS 9.2 software (SAS Institute Inc., Cary, North Carolina, USA). Continuous variables were summarized descriptively by sample size, mean, standard deviation (SD), median, minimum, and maximum. Discrete variables were summarized descriptively using counts and percentages. Assay results were treated as positive or negative as previously approved by the FDA: 1$)$ HER2 IHC negative ( 0 or $1+)$ and positive $(2+$ or $3+)$ and 2) HER2 \& CEN17 BISH positive $(H E R 2 / C E N 17$ ratio $\geq 2.0)$ and negative $($ HER2/CEN17 ratio $<2.0)$.

The concordance of the results from pairs of readers and among pairs of tests was calculated according to the following (Table 1):

Where $x^{+}$is the number of $\mathrm{X}$ positive samples, $x^{-}$is the number of $\mathrm{X}$ negative samples, $y^{+}$is the number of $\mathrm{Y}$ positive samples, $y^{-}$is the number of $\mathrm{Y}$ negative samples, $a$ is the number of $x^{+} y^{+}$samples, $b$ is the number of $x^{+} y^{-}$samples, $c$ is the number of $x^{-} y^{+}$samples, and $d$ is the number of $x^{-} y^{-}$samples.

For analyses in which comparator X was a "test" group and comparator $\mathrm{Y}$ was a "reference" group (e.g., X was the HER2 gene-protein test and Y was the HER2 IHC test), concordance was assessed by calculating positive percent agreement (PPA) and negative percent agreement (NPA) among comparators according to the following formulas:

$$
\begin{aligned}
& \mathrm{PPA}=[a /(a+c)] \times 100 \% \\
& \mathrm{NPA}=[d /(b+d)] \times 100 \%
\end{aligned}
$$

When neither comparator was considered to be the reference (e.g., $\mathrm{X}$ and $\mathrm{Y}$ were two different scorers), concordance was determined by calculating average positive agreement (APA) and average negative agreement (ANA) according to the following formulas [11]:

$$
\begin{aligned}
& \mathrm{APA}=[2 a /(2 a+b+c)] \times 100 \% \\
& \mathrm{ANA}=[2 d /(2 d+b+c)] \times 100 \%
\end{aligned}
$$

The overall concordance was calculated as the overall percent agreement (OPA) for all concordance analyses according to the formula:

$$
\mathrm{OPA}=[(a+d) /(a+b+c+d)] \times 100 \%
$$

Two-sided 95\% confidence intervals were calculated using the score method. Kappa coefficients were calculated for assay agreements for each analysis.

Table 1 Joint Frequency Table for HER2 Staining Status

\begin{tabular}{llll}
\hline & & \multicolumn{2}{l}{ Comparator Y } \\
\cline { 2 - 4 } & & $\boldsymbol{y}^{+}$ & $\boldsymbol{y}^{-}$ \\
\hline Comparator X & $x^{+}$ & $a$ & $b$ \\
\cline { 2 - 4 } & $x^{-}$ & $c$ & $d$ \\
\hline
\end{tabular}




\section{Results}

Development of the HER2 gene-protein assay

The optimized staining protocol for simultaneous visualization of HER2 protein, the HER2 gene, and CEN17 on the same tissue is shown in Figure 1. As shown in the figure, the HER2 IHC detection is performed before the HER2 \& CEN17 BISH detection, as this sequence was found to be the most sensitive for HER2 protein detection (data not shown). The major technical difficulties encountered in combining the DAB-based HER2 IHC assay and the HER2 \& CEN17 BISH assay, which uses a DNP-labeled HER2 probe, were high background staining of the nuclei and a change in the DAB staining appearance on FFPE tissue sections (Figure 2A, B). When the BISH step was carried out after the DAB-based IHC step, the DNP hapten on the HER2 DNA probe bound non-specifically to nuclei and to some of the DAB staining, thus producing silver background staining during the $\mathrm{BISH}$ detection step for DNP-labeled DNA. The use of additional washing steps failed to reduce this artifactual background staining (data not shown), but the inclusion of naphthol phosphate in the hybridization buffer during hybridization was found to block DNP-DAB interaction, thereby eliminating the silver background staining (Figure 2C, D).

\section{The optimized HER2 gene-protein assay appropriately} stains clinical breast-cancer tissue samples

Using a previously FDA-approved HER2 IHC assay, we identified clinical breast cancer tissue samples with HER2 expression scores of 3+ (Figure 3A, B, C), 2+ (Figure 3D, E, F), 1+ (Figure 3G, H, I), and 0 (Figure 3J, K, L). As expected, a previously FDA-approved HER2 and CEN17 $\mathrm{BISH}$ assay resulted in labeling of the HER2 gene and CEN17 targets in the same area of each tissue core as black and red dots, respectively (Figure 3B, E, H, K). The optimized HER2 gene-protein assay (with naphthol phosphate) stained the HER2 protein, HER2 gene, and CEN17 targets as in the separate IHC and BISH assays (Figure 3C,

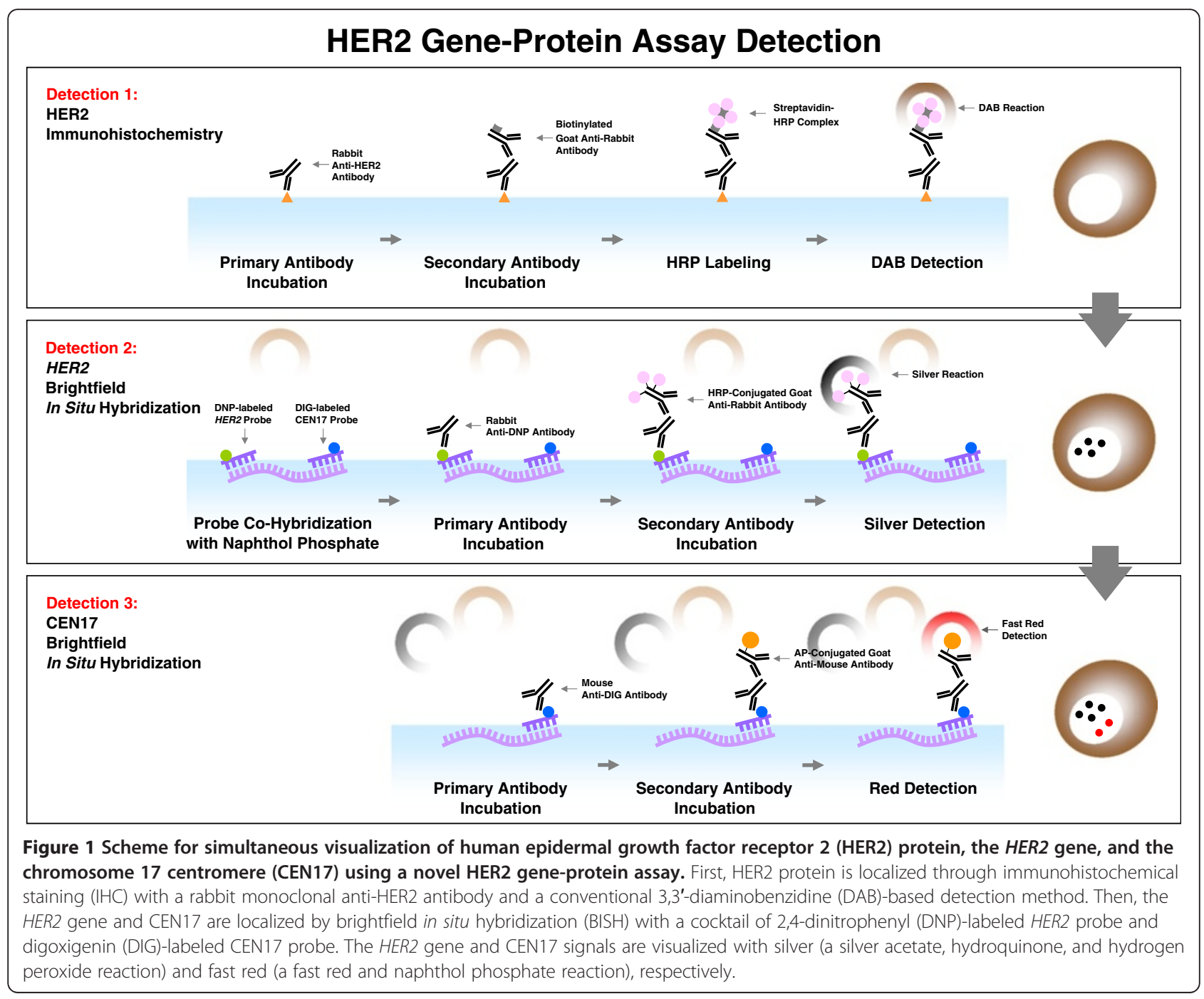




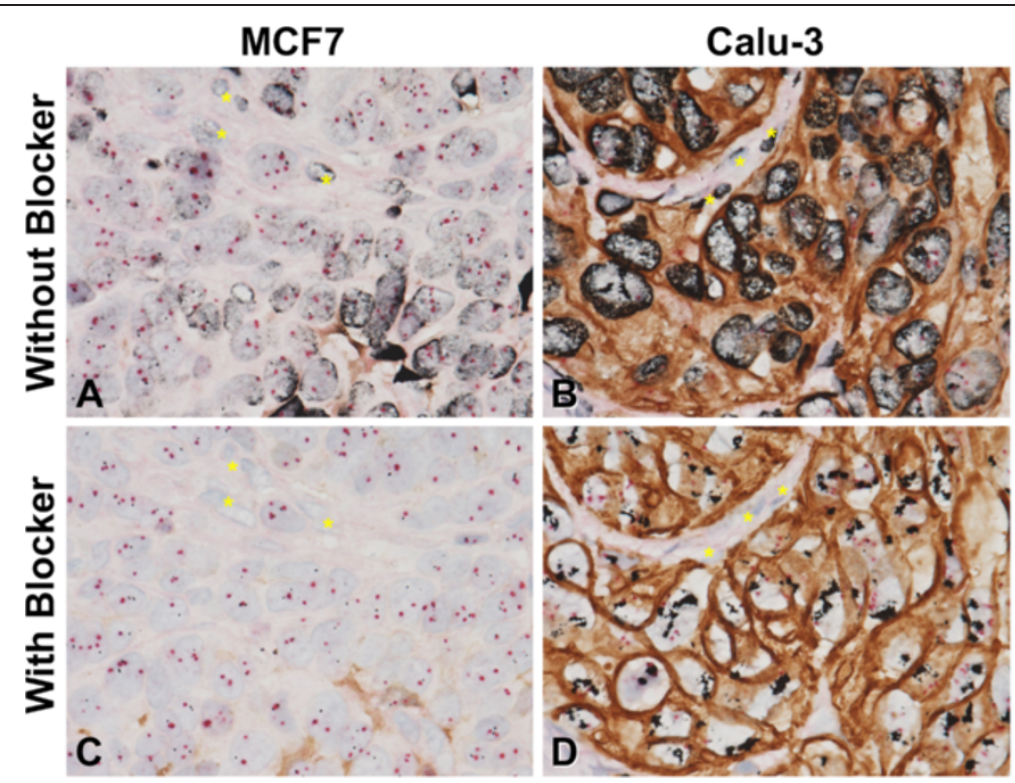

Figure 2 Naphthol phosphate blocks silver background staining resulting from the HER2 \& CEN17 BISH procedure. Images show HER2 gene-protein staining results obtained without (A, B) or with naphthol phosphate (C, D) on formalin-fixed, paraffin-embedded (FFPE) HER2negative MCF7 (A, C) and HER2-positive Calu-3 (B, D) xenograft tumors. In the absence of naphthol phosphate, non-specific silver deposition from the HER2 BISH detection procedure obscures the BISH signals for the HER2 gene and CEN17 targets (A, B) whereas the use of a BISH hybridization buffer containing naphthol phosphate eliminates the non-specific silver deposition (C, D). Some silver deposition was also seen in DAB staining (A). In the absence of naphthol phosphate, non-specific silver deposition occurred in mouse cells (yellow asterisks) (A, B) and mouse cells were confirmed without HER2 and CEN17 BISH signals by using naphthol phosphate (C, D). 60X.

F, I, J). Specifically, HER2 protein was visualized as complete membrane staining in the $3+$ sample (Figure 3A, $\mathrm{C})$, less complete membrane staining in the $2+$ sample (Figure 3D, F), faint membrane staining in the $1+$ sample (Figure 3G, I), and no staining in the 0 sample (Figure 3J, $\mathrm{L})$, and the HER2 gene and CEN17 targets appeared as black and red dots, respectively. Thus, the multiplex HER2 gene-protein assay co-localized the HER2 protein, HER2 gene, and CEN17 targets appropriately.

\section{Performance of the optimized HER2 gene-protein Assay}

The optimized HER2 gene-protein assay in determining both HER2 protein (IHC) and HER2 gene (BISH) status simultaneously demonstrated the usefulness of the assay on equivocal (2+) and negative (0) HER2 IHC samples of different HER2 ISH statuses (Figure 4). It readily distinguished the HER2 ISH positive samples from the HER2 ISH negative samples in both the IHC equivocal (Figure 4A and $\mathrm{B}$, respectively) and the IHC-negative cases (Figure $4 \mathrm{C}$ and D, respectively).

For one breast cancer tissue core, the HER2 gene-protein assay revealed the heterogeneity of HER2 protein status with HER2 IHC 3+, 2+, and 1+ cell populations visible within the same area (Figure 5A). It also showed that the HER2 IHC 3+ cell population contained dispersed HER2 gene copies while the HER2 IHC $2+$ and $1+$ cell populations contained clustered HER2 gene copies. The HER2 gene-protein assay also detected the scattered HER2 positive cell populations within a breast cancer tissue core (Figure 5B). Isolated HER2 IHC positive and HER2 \& CEN17 BISH positive tumor cells surrounded by the interstitial tissue were clearly visible (Figure 5B, insert).

Because six of the 189 breast tissue cores examined contained no tumor cells (Table 2), all statistical analyses were based on the 183 remaining tissue cores with tumor cells. All of these cores yielded evaluable IHC results (from both the single and combined assays) for each of the three readers in this study (Table 2). For the $\mathrm{BISH}$ results, the percentage of evaluable cores ranged from $90.7 \%$ (Reader A, HER2 \& CEN17 BISH) to 98.4\% (Reader C, HER2 gene-protein assay). The HER2 geneprotein assay consistently yielded a higher number of evaluable cores than the HER2 \& CEN17 BISH assay, although most of these were evaluable (Table 2). The superiority of the HER2 gene-protein assay over the HER2 \& CEN17 BISH assay in yielding BISH results ranged by reader from approximately $7 \%$ to $13 \%$.

The HER2 IHC score distributions for the HER2 IHC assay relative to the HER2 gene-protein assay were comparable for each reader and the distributions of positive $v s$. negative HER2 IHC assessments were consistent from assay to assay and also from reader to reader (Table 3). For both types of HER2 IHC and for all readers, approximately $30 \%$ of HER 2 IHC assessments were positive and approximately $70 \%$ were negative (Table 3 ). For each reader, the average HER2 gene count, CEN17 count, and 

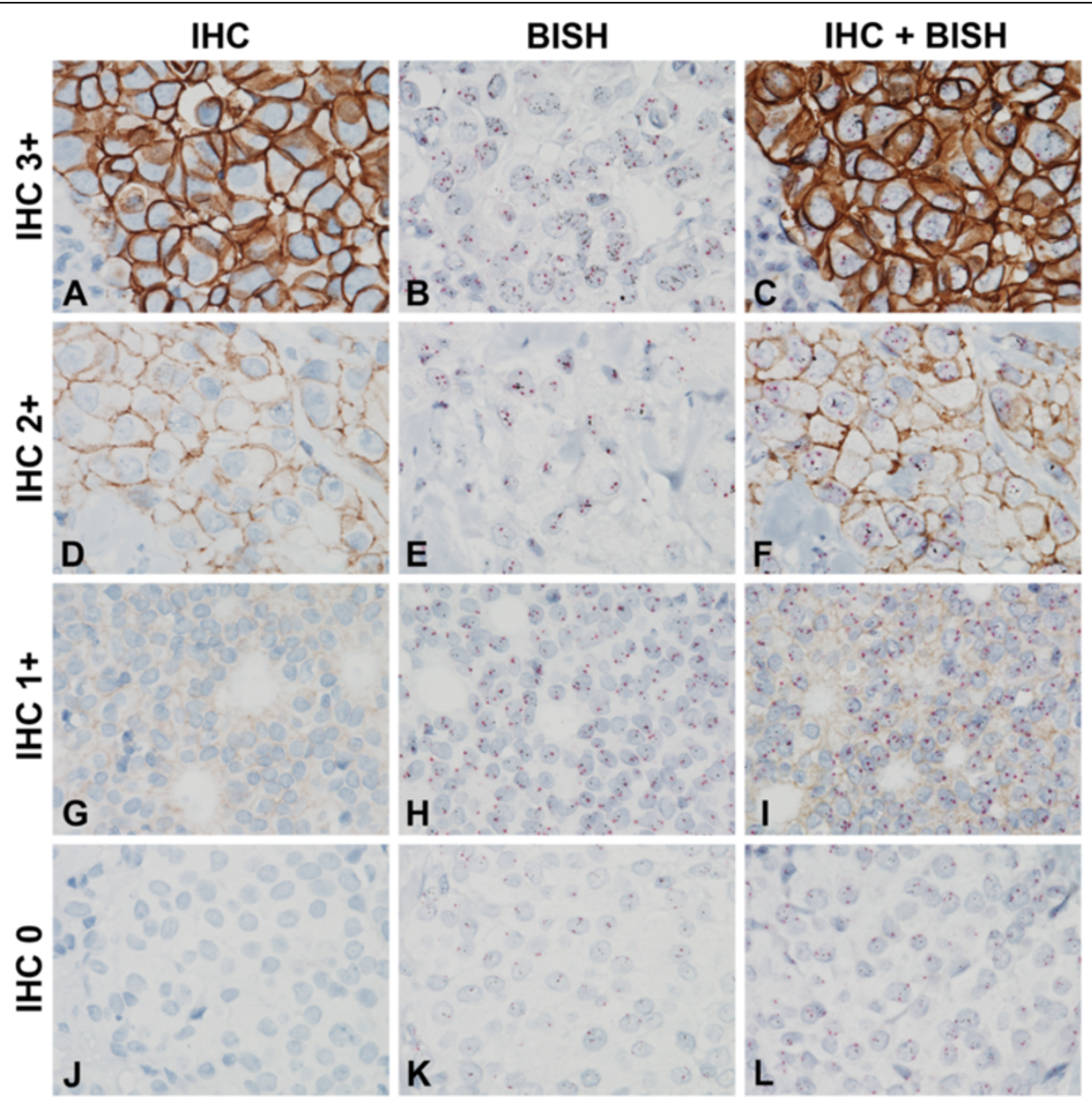

Figure 3 The HER2 gene-protein assay yields appropriate staining of HER2 protein, the HER2 gene, and CEN17 in FFPE clinical breast cancer tissues. Tissues with HER2 IHC scores of $3+(\mathbf{A}-\mathbf{C}), 2+(\mathbf{D}-\mathbf{F}), 1+(\mathbf{G}-\mathbf{I})$, and $0(\mathbf{J}-\mathbf{L})$ were subjected to HER2 IHC assay $(\mathbf{A}, \mathbf{D}, \mathbf{G}, \mathbf{J})$, HER2 \& CEN17 BISH assay $(\mathbf{B}, \mathbf{E}, \mathbf{H}, \mathbf{K})$, or the HER2 gene-protein assay $(\mathbf{C}, \mathbf{F}, \mathbf{I}, \mathbf{L})$ using tissue microarray slides. HER2 IHC assay yielded the expected HER2 protein staining $(\mathbf{A}, \mathbf{D}, \mathbf{G}, \mathbf{J})$ and the separate HER2 \& CEN17 BISH assay yielded the expected staining of the HER2 gene (black dots) and CEN17 (red dots) $(\mathbf{B}, \mathbf{E}, \mathbf{H}, \mathbf{K})$. The combined assay yielded both the appropriate HER2 protein staining and the appropriate HER2 gene and CEN17 staining $(\mathbf{C}, \mathbf{F}, \mathbf{I}, \mathbf{L})$. [All images $60 \mathrm{X}$.]

HER2/CEN17 ratio were very similar between the HER2 \& CEN17 BISH and the HER2 gene-protein assay, and the HER2 gene amplification status was comparable between the two assays (Table 4). The distribution of amplified $v s$. non-amplified HER2 \& CEN17 BISH assessments was consistent from assay to assay and also from reader to reader (Table 4). For both types of HER2 \& CEN17 BISH and for all readers, approximately $25-27 \%$ of samples were HER2 amplified and approximately $67-72 \%$ were nonamplified when unevaluable tissue cores were included in the calculation of percentage (Table 4).

In concordance analyses, the HER2 IHC assay was taken as the reference assay for the HER2 protein expression results of the HER2 gene-protein assay (Table 5). The IHC positive agreement ranged from 97.9\% (Reader B) to $100 \%$ (Readers A and C) and the IHC negative agreement ranged from $97.8 \%$ (Reader B) to $99.2 \%$ (Reader $\mathrm{C}$ ). The overall agreement ranged from $97.8 \%$ (Reader B) to $99.5 \%$ (Reader C) and the kappa coefficient ranged from 0.94 (Reader B) to 0.99 (Reader C). These excellent agreement rates indicate that HER2 status diagnosis based on the HER2 IHC part of the combined HER2 gene-protein assay is essentially equivalent to that based on the individual HER2 IHC assay.

In concordance analyses, the HER2 \& CEN17 BISH assay was taken as the reference assay for the HER2 \& CEN17 BISH results of the HER2 gene-protein assay (Table 6). The HER2 \& CEN17 BISH positive agreement ranged from $94 \%$ (Reader B) to $95.6 \%$ (Reader A) and the BISH negative agreement ranged from 96.2\% (Reader C) to $99.2 \%$ (Reader B). The overall percent agreement ranged from $96 \%$ (Reader C) to $97.7 \%$ (Reader B) and the kappa coefficient ranged from 0.89 (Reader $\mathrm{C}$ ) to 0.94 (Readers $\mathrm{A}$ and $\mathrm{B}$ ), indicating that the HER2 diagnosis based on the HER2 \& CEN17 BISH part of the 


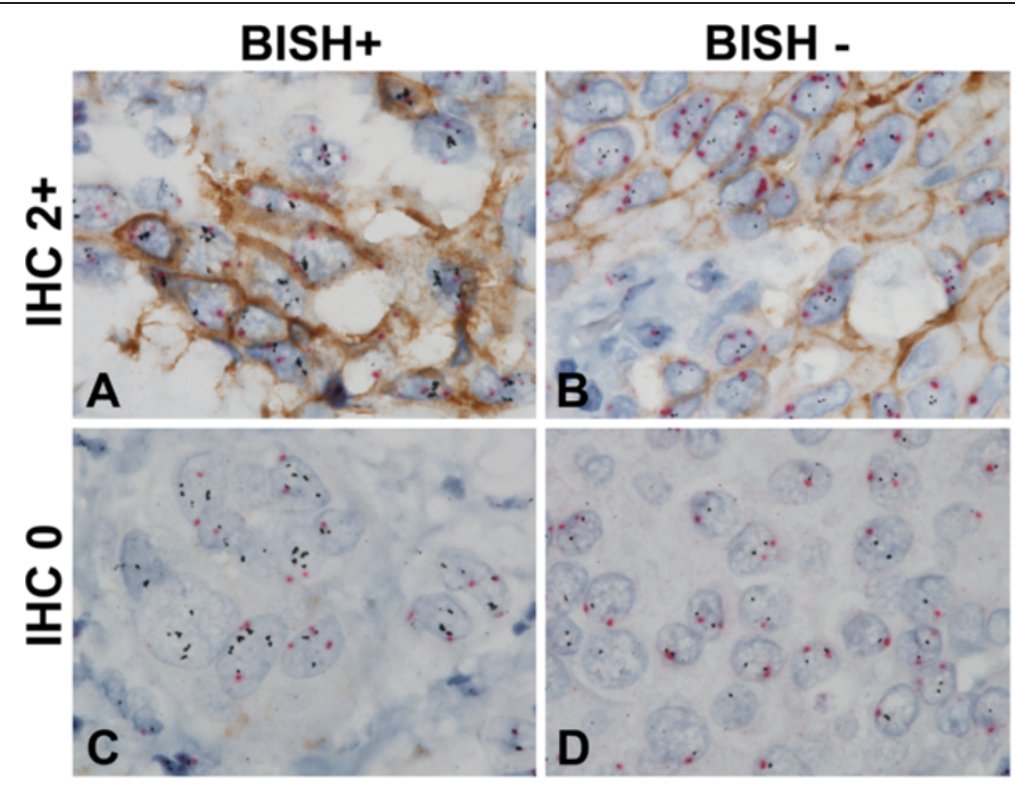

Figure 4 Differentiation of HER2 gene status in HER2 protein equivocal (IHC 2+) or negative (IHC 0) breast cancer tissues using the HER2 gene-protein assay. The HER2 gene-protein assay carried out on FFPE breast cancer tissue microarray slides was able to differentiate HER2 IHC 2+ cases that were HER2 \& CEN17 BISH positive (A) and negative (B). It also distinguished HER2 IHC 0 cases that were HER2 \& CEN17 BISH positive (C) and negative (D). [All images 100x.].

HER2 gene-protein assay is essentially equivalent to that based on the HER2 \& CEN17 BISH only assay.

Analyses of the combined HER2 IHC and HER2 \& CEN17 BISH data from each reader for the individual IHC and BISH assays and the gene-protein assay are shown in Table 7. For analyses using the HER2 geneprotein assay, the status of a tissue core was defined as HER2 positive if either the HER2 protein status was positive or the HER2 gene status was amplified; otherwise, it was defined as negative. This algorithm is consistent with clinical practice, in which a patient is treated as HER2 positive if either assay shows an amplified HER2 status. The results of the individual HER2 \& CEN17 BISH and HER2 IHC assays were similarly combined to yield the overall HER2 status that served as the reference for the combined assay. The HER2 positive agreement ranged from $94.3 \%$ (Reader B) to $98 \%$ (Reader A) and the HER2 negative agreement ranged from $97.5 \%$ (Reader C) to $98.3 \%$ (Reader B). The overall agreement ranged from $97.1 \%$ (Readers B and C) to $98.2 \%$ (Reader A) and the kappa coefficient ranged from 0.93 (Readers $\mathrm{B}$ and C) to 0.96 (Reader A), indicating that HER2

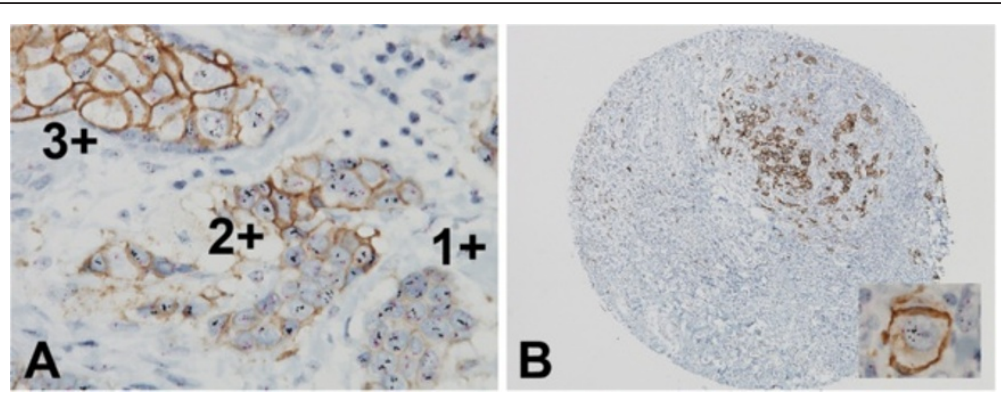

Figure 5 Results of HER2 gene-protein staining of FFPE breast cancer tissues exhibiting heterogeneity of HER2 positive tumor cell populations or isolated tumor cell populations. (A) The HER2 gene-protein assay demonstrated the heterogeneity of HER2 positive tumor cell populations in FFPE breast cancer tissues. In the sample shown, cell populations with HER2 IHC scores of 3+, 2+, and 1+ neighbor each other and all tumor populations present amplified HER2 gene. However, the HER2 IHC 3+ tumor cell population contains dispersed HER2 gene copies while the HER2 IHC 2+ and 1+ population contains clustered HER2 gene copies [40X]. (B) The HER2 gene-protein assay clearly visualized small groups of HER2 IHC 3+ breast cancer cells [4X]. The insert shows an isolated individual HER2 IHC positive tumor cell with HER2 gene amplification $[100 \times]$. 
Table 2 Disposition of study cases

\begin{tabular}{|c|c|c|c|c|}
\hline Parameter & $\begin{array}{l}\text { Count } \\
n\end{array}$ & $\begin{array}{c}\text { Reader } A \\
n(\%)\end{array}$ & $\begin{array}{c}\text { Reader B } \\
n(\%)\end{array}$ & $\begin{array}{c}\text { Reader C } \\
n(\%)\end{array}$ \\
\hline Total number of tissue cores & 189 & & & \\
\hline $\begin{array}{l}\text { Number of tissue cores } \\
\text { without tumor }\end{array}$ & 6 & & & \\
\hline Number of cores with tumor & 183 & & & \\
\hline $\begin{array}{l}\text { Number of cores with evaluable } \\
\text { gene-protein } \mathrm{IHC} \text { results }\end{array}$ & & $\begin{array}{c}183 \\
(100.0)\end{array}$ & $\begin{array}{c}183 \\
(100.0)\end{array}$ & $\begin{array}{c}183 \\
(100.0)\end{array}$ \\
\hline $\begin{array}{l}\text { Number of cores with evaluable } \\
\text { single } \mathrm{IHC} \text { results }\end{array}$ & & $\begin{array}{c}183 \\
(100.0)\end{array}$ & $\begin{array}{c}183 \\
(100.0)\end{array}$ & $\begin{array}{c}183 \\
(100.0)\end{array}$ \\
\hline $\begin{array}{l}\text { Number of cores with evaluable } \\
\text { gene-protein BISH results }\end{array}$ & & $\begin{array}{c}179 \\
(97.8)\end{array}$ & $\begin{array}{c}179 \\
(97.8)\end{array}$ & $\begin{array}{c}180 \\
(98.4)\end{array}$ \\
\hline $\begin{array}{l}\text { Number of cores with evaluable } \\
\text { single BISH results }\end{array}$ & & $\begin{array}{c}166 \\
(90.7)\end{array}$ & $\begin{array}{c}172 \\
(94.0)\end{array}$ & $\begin{array}{c}173 \\
(94.5)\end{array}$ \\
\hline
\end{tabular}

IHC: immunohistochemistry; BISH: brightfield in situ hybridization.

diagnosis based on the BISH and IHC results of the HER2 gene-protein assay is essentially equivalent to that based on the separate HER2 \& CEN17 BISH and HER2 IHC assays.

Analyses of the agreement among readers were performed separately for the HER2 IHC protein statuses from the single IHC assay and the gene-protein assay, for the HER2 BISH gene statuses from the single assay and the gene-protein assay, for the combined HER2 IHC and HER2 \& CEN17 BISH results from two separate HER2 \& CEN17 BISH and HER2 IHC assays and the gene-protein assay (Table 8). Each of the three possible reader pairs was assessed for each assay. Because no individual reader was considered the reference, reader-toreader agreement was assessed by calculating APA and ANA. Of the 24 calculated reader-to-reader agreement rates, 17 were greater than $95 \%, 5$ were between $90 \%$ and

Table 3 IHC descriptive statistics

\begin{tabular}{|c|c|c|c|c|c|c|}
\hline & Reader A & & Reader B & & Reader C & \\
\hline & $\begin{array}{l}\text { Gene- } \\
\text { protein } \\
\mathrm{IHC} \\
(\mathrm{N}=183)\end{array}$ & $\begin{array}{c}\text { Single } \\
\text { IHC } \\
(N=183)\end{array}$ & $\begin{array}{c}\text { Gene- } \\
\text { protein } \\
\text { IHC } \\
(\mathrm{N}=183)\end{array}$ & $\begin{array}{c}\text { Single } \\
\text { IHC } \\
(N=183)\end{array}$ & $\begin{array}{c}\text { Gene- } \\
\text { protein } \\
\text { IHC } \\
(\mathrm{N}=183)\end{array}$ & $\begin{array}{c}\text { Single } \\
\text { IHC } \\
(\mathrm{N}=183)\end{array}$ \\
\hline IHC sco & re, $\mathrm{n}(\%)$ & & & & & \\
\hline 0 & 84 (45.9) & $90(49.2)$ & $99(54.1)$ & $\begin{array}{c}109 \\
(59.6)\end{array}$ & $110(60.1)$ & $\begin{array}{c}115 \\
(62.8)\end{array}$ \\
\hline $1+$ & $47(25.7)$ & $43(23.5)$ & $34(18.6)$ & $26(14.2)$ & $18(9.8)$ & $14(7.7)$ \\
\hline $2+$ & $10(5.5)$ & $8(4.4)$ & $7(3.8)$ & $6(3.3)$ & $8(4.4)$ & $10(5.5)$ \\
\hline $3+$ & $42(23.0)$ & $42(23.0)$ & $43(23.5)$ & $42(23.0)$ & $47(25.7)$ & $44(24.0)$ \\
\hline IHC ass & sessment, $\mathrm{n}$ & $(\%)$ & & & & \\
\hline Positive & $52(28.4)$ & $50(27.3)$ & $50(27.3)$ & $48(26.2)$ & $55(30.1)$ & $54(29.5)$ \\
\hline$\overline{\text { Negative }}$ & e131 (71.6) & $\begin{array}{c}133 \\
(72.7)\end{array}$ & $133(72.7)$ & $\begin{array}{c}135 \\
(73.8)\end{array}$ & $128(69.9)$ & $\begin{array}{c}129 \\
(70.5)\end{array}$ \\
\hline
\end{tabular}

IHC: immunohistochemistry.
Table 4 BISH descriptive statistics

\begin{tabular}{|c|c|c|c|c|c|}
\hline Reader A & & Reader B & & Reader C & \\
\hline $\begin{array}{c}\text { Gene- } \\
\text { protein } \\
\text { BISH } \\
(\mathrm{N}=183)\end{array}$ & $\begin{array}{c}\text { Single } \\
\text { BISH } \\
(N=183)\end{array}$ & $\begin{array}{c}\text { Gene- } \\
\text { protein } \\
\text { BISH } \\
(\mathrm{N}=183)\end{array}$ & $\begin{array}{c}\text { Single } \\
\text { BISH } \\
(N=183)\end{array}$ & $\begin{array}{c}\text { Gene- } \\
\text { protein } \\
\text { BISH } \\
(\mathrm{N}=183)\end{array}$ & $\begin{array}{c}\text { Single } \\
\text { BISH } \\
(N=183)\end{array}$ \\
\hline
\end{tabular}

\section{HER2 mean}

\begin{tabular}{lcccccc}
\hline $\mathrm{n}$ & 179 & 166 & 179 & 172 & 180 & 173 \\
\hline Mean & 4.273 & 4.643 & 5.199 & 5.452 & 3.333 & 3.176 \\
(SD) & $(4.208)$ & $(4.567)$ & $(6.280)$ & $(6.693)$ & $(2.851)$ & $(2.362)$ \\
\hline Median & 2.200 & 2.225 & 1.900 & 1.900 & 2.000 & 1.950 \\
\hline Min, max & $1.00,21.10$ & 1.00, & 1.00, & 1.00, & 1.00, & 1.20, \\
& & 22.60 & 40.20 & 40.40 & 16.25 & 11.10 \\
\hline \multicolumn{7}{l}{ CEN17 mean } \\
\hline n & 179 & 166 & 179 & 172 & 180 & 173 \\
\hline Mean & 1.803 & 1.868 & 1.566 & 1.540 & 1.606 & 1.613 \\
(SD) & $(0.496)$ & $(0.501)$ & $(0.356)$ & $(0.339)$ & $(0.335)$ & $(0.296)$ \\
\hline Median & 1.650 & 1.750 & 1.500 & 1.450 & 1.550 & 1.550 \\
\hline Min, max & $1.00,3.50$ & $1.00,3.95$ & $1.00,2.80$ & $1.00,2.95$ & $1.05,2.60$ & $1.00,2.65$
\end{tabular}

\section{HER2/CEN17 ratio}

\begin{tabular}{lcccccc}
\hline $\mathrm{n}$ & 179 & 166 & 179 & 172 & 180 & 173 \\
\hline Mean & 2.485 & 2.521 & 3.344 & 3.637 & 2.100 & 2.004 \\
(SD) & $(2.613)$ & $(2.533)$ & $(3.952)$ & $(4.620)$ & $(1.802)$ & $(1.564)$ \\
\hline Median & 1.170 & 1.190 & 1.310 & 1.355 & 1.255 & 1.240 \\
\hline Min, max & 0.67, & 0.76, & 0.67, & 0.60, & 0.74, & 0.82, \\
& 10.82 & 11.02 & 19.14 & 26.06 & 8.46 & 9.25 \\
\hline
\end{tabular}

Amplification status, $\mathrm{n}(\%)$

\begin{tabular}{lllllll}
\hline Amplified & $46(25.1)$ & $46(25.1)$ & $49(26.8)$ & $50(27.3)$ & $47(25.7)$ & $43(23.5)$
\end{tabular}

\begin{tabular}{lllllll}
\hline Non- & $133(72.7)$ & 120 & $130(71.0)$ & 122 & $133(72.7)$ & 130
\end{tabular}

\begin{tabular}{|c|c|}
\hline amplified & (1) \\
\hline
\end{tabular}

\begin{tabular}{lllllll}
\hline N/A & $4(2.2)$ & $17(9.3)$ & $4(2.2)$ & $11(6.0)$ & $3(1.6)$ & $10(5.5)$
\end{tabular}

BISH: brightfield in situ hybridization; HER2: human epidermal growth factor receptor 2; CEN17: chromosome 17 centromere.

$95 \%$, and 2 were close to $90 \%$, indicating excellent interreader agreement on all assays. The APA and ANA for all reader pairs based on HER2 IHC results, HER2 \& CEN17 $\mathrm{BISH}$ results, and combined HER2 IHC and HER2 \& CEN17 BISH results were always higher in the HER2 gene-protein assay than in two separate HER2 IHC and HER2 \& CEN17 BISH assays and the difference ranged from $0.1-5.6 \%$ (Table 9). Thus, when the HER2 \& CEN17 BISH and HER2 IHC assays were combined into a single test as the gene-protein assay, inter-reader agreement consistently improved over two separate HER2 IHC and HER2 \& CEN17 BISH assays.

\section{Discussion}

To avoid subjecting breast cancer patients to unnecessary financial burden and significant side effects, the selection of those most likely to response to HER2-directed therapy must be accurate. Our original motivation for developing the tricolor HER2 gene-protein assay was to deliver a tissue-based HER2 test that is more accurate than the 
Table 5 Gene-protein IHC (comparator) vs. single IHC (reference) agreement analyses

\begin{tabular}{|c|c|c|c|c|}
\hline & & Single IHC & & \\
\hline & Gene-protein IHC & Positive & Negative & Total \\
\hline \multirow[t]{7}{*}{ Reader A } & Positive & 50 & 2 & 52 \\
\hline & Negative & 0 & 131 & 131 \\
\hline & Total & 50 & 133 & 183 \\
\hline & PPA: n/N (\%) (95\% Cl) & $\begin{array}{l}50 / 50(100.0) \\
(92.9-100.0)\end{array}$ & & \\
\hline & NPA: n/N (\%) (95\% Cl) & $\begin{array}{l}\text { 131/133 (98.5) } \\
(94.7-99.6)\end{array}$ & & \\
\hline & OPA: n/N (\%) (95\% Cl) & $\begin{array}{l}\text { 181/183 (98.9) } \\
(96.1-99.7) \\
\end{array}$ & & \\
\hline & Kappa coefficient $(95 \% \mathrm{Cl})$ & $0.97(0.94-1.00)$ & & \\
\hline \multirow[t]{7}{*}{ Reader B } & Positive & 47 & 3 & 50 \\
\hline & Negative & 1 & 132 & 133 \\
\hline & Total & 48 & 135 & 183 \\
\hline & PPA: n/N (\%) $(95 \%$ Cl) & $\begin{array}{l}47 / 48(97.9) \\
(89.1-99.6)\end{array}$ & & \\
\hline & NPA: n/N (\%) (95\% Cl) & $\begin{array}{l}132 / 135(97.8) \\
(93.7-99.2)\end{array}$ & & \\
\hline & OPA: n/N (\%) (95\% Cl) & $\begin{array}{l}179 / 183(97.8) \\
(94.5-99.1)\end{array}$ & & \\
\hline & Kappa coefficient $(95 \% \mathrm{Cl})$ & $0.94(0.89-1.00)$ & & \\
\hline \multirow[t]{7}{*}{ Reader C } & Positive & 54 & 1 & 55 \\
\hline & Negative & 0 & 128 & 128 \\
\hline & Total & 54 & 129 & 183 \\
\hline & PPA: n/N (\%) (95\% Cl) & $\begin{array}{l}54 / 54(100.0) \\
(93.4-100.0)\end{array}$ & & \\
\hline & NPA: n/N (\%) (95\% Cl) & $\begin{array}{l}128 / 129(99.2) \\
(95.7-99.9)\end{array}$ & & \\
\hline & OPA: n/N (\%) (95\% Cl) & $\begin{array}{l}182 / 183(99.5) \\
(97.0-99.9)\end{array}$ & & \\
\hline & Kappa coefficient (95\% Cl) & $0.99(0.96-1.00)$ & & \\
\hline
\end{tabular}

IHC: immunohistochemistry; PPA: positive percent agreement; NPA: negative percent agreement; OPA: overall percent agreement.

separate HER2 IHC and HER2 ISH assays. Because HER2 IHC assays are technically easier to perform than HER2 FISH assays, $80 \%$ of newly diagnosed breast cancer cases in the US are analyzed for HER2 status using HER2 IHC [12]. However, the technical issues that can complicate HER2 IHC assays, such as unstandardized antigen retrieval protocols and multiple antibody clones, have led to the recommendation of HER2 ISH as the first-line assay for HER2 status assessment [13]. Tissue quality for HER2 ISH assays can be assessed using the ISH signals in normal cells surrounding the tumor cells as internal controls. In contrast, assessment of tissue quality for HER2 IHC assays is difficult; because there is no proven internal control, false negatives can result [14].

A 2007 report of the American Society of Clinical Oncology-College of American Pathologists (ASCO-CAP) concluded that $20 \%$ of HER2 assays performed in the field
Table 6 Gene-protein BISH (comparator) vs. single BISH (reference) agreement analyses

\begin{tabular}{|c|c|c|c|c|}
\hline & & Single BISH & & \\
\hline & Gene-protein BISH & Amplified & Non-amplified & Total \\
\hline \multirow[t]{7}{*}{ Reader A } & Amplified & 43 & 2 & 45 \\
\hline & Non-amplified & 2 & 118 & 120 \\
\hline & Total & 45 & 120 & 165 \\
\hline & PPA: n/N (\%) (95\% Cl) & $\begin{array}{c}43 / 45(95.6) \\
(85.2-98.8)\end{array}$ & & \\
\hline & NPA: n/N (\%) $(95 \% \mathrm{Cl})$ & $\begin{array}{c}118 / 120(98.3) \\
(94.1-99.5)\end{array}$ & & \\
\hline & OPA: n/N (\%) (95\% Cl) & $\begin{array}{c}161 / 165(97.6) \\
(93.9-99.1)\end{array}$ & & \\
\hline & $\begin{array}{l}\text { Kappa coefficient } \\
(95 \% \mathrm{Cl})\end{array}$ & $0.94(0.88-1.00)$ & & \\
\hline \multirow[t]{7}{*}{ Reader B } & Amplified & 47 & 1 & 48 \\
\hline & Non-amplified & 3 & 121 & 124 \\
\hline & Total & 50 & 122 & 172 \\
\hline & PPA: n/N (\%) (95\% Cl) & $\begin{array}{c}47 / 50(94.0) \\
(83.8-97.9)\end{array}$ & & \\
\hline & NPA: n/N (\%) $(95 \% \mathrm{Cl})$ & $\begin{array}{c}121 / 122(99.2) \\
(95.5-99.9)\end{array}$ & & \\
\hline & OPA: n/N (\%) (95\% Cl) & $\begin{array}{c}168 / 172(97.7) \\
(94.2-99.1)\end{array}$ & & \\
\hline & $\begin{array}{l}\text { Kappa coefficient } \\
(95 \% \mathrm{Cl})\end{array}$ & $\begin{array}{c}0.94 \\
(0.89-1.00)\end{array}$ & & \\
\hline \multirow[t]{7}{*}{ Reader C } & Amplified & 41 & 5 & 46 \\
\hline & Non-amplified & 2 & 125 & 127 \\
\hline & Total & 43 & 130 & 173 \\
\hline & PPA: n/N (\%) (95\% Cl) & $\begin{array}{c}41 / 43(95.3) \\
(84.5-98.7)\end{array}$ & & \\
\hline & NPA: n/N (\%) $(95 \% \mathrm{Cl})$ & $\begin{array}{c}125 / 130(96.2) \\
(91.3-98.3)\end{array}$ & & \\
\hline & OPA: n/N (\%) (95\% Cl) & $\begin{array}{c}166 / 173(96.0) \\
(91.9-98.0)\end{array}$ & & \\
\hline & $\begin{array}{l}\text { Kappa coefficient } \\
(95 \% \mathrm{Cl})\end{array}$ & $0.89(0.82-0.97)$ & & \\
\hline
\end{tabular}

BISH: brightfield in situ hybridization; PPA: positive percent agreement; NPA negative percent agreement; OPA: overall percent agreement.

were not accurate and established guidelines to improve the accuracy of HER2 testing in breast cancer [2]. However, a 2008 follow up study using survey results from 757 laboratories indicated that substantial gaps remained in assay validation [15]. Lee et al. [1] also reported that only $15 \%$ (7/46) of reported studies of the concordance between HER2 IHC and HER2 FISH results achieved the ASCOCAP guideline of $95 \%$ or greater concordance.

Breast tumor heterogeneity is a major cause of discordance between HER2 IHC and HER2 FISH assay results $[16,17]$ and approximately $5-30 \%$ of HER2 positive breast cancer cases exhibit intratumoral genetic heterogeneity [18]. Subtle HER2 genetic heterogeneity of tumor cells has been reported among equivocal cases $[17,19]$. An alternative method for determining HER2 status from FFPE 
Table 7 Gene-protein IHC/BISH (comparator) vs. single IHC/BISH (reference) agreement analyses

\begin{tabular}{|c|c|c|c|c|}
\hline & & Single IHC/BISF & $\mathrm{H}$ assay & \\
\hline & $\begin{array}{l}\text { Gene-protein } \\
\text { IHC/BISH }\end{array}$ & Positive & Negative & Total \\
\hline \multirow[t]{7}{*}{ Reader A } & Positive & 50 & 2 & 52 \\
\hline & Negative & 1 & 112 & 113 \\
\hline & Total & 51 & 114 & 165 \\
\hline & PPA: n/N (\%) $(95 \%$ Cl) & $\begin{array}{l}50 / 51(98.0) \\
(89.7-99.7)\end{array}$ & & \\
\hline & NPA: n/N (\%) (95\% Cl) & $\begin{array}{l}112 / 114(98.2) \\
(93.8-99.5)\end{array}$ & & \\
\hline & OPA: n/N (\%) (95\% Cl) & $\begin{array}{l}162 / 165(98.2) \\
(94.8-99.4)\end{array}$ & & \\
\hline & Kappa coefficient $(95 \%$ Cl) & $0.96(0.91-1.00)$ & & \\
\hline \multirow[t]{7}{*}{ Reader B } & Positive & 50 & 2 & 52 \\
\hline & Negative & 3 & 117 & 120 \\
\hline & Total & 53 & 119 & 172 \\
\hline & PPA: n/N (\%) (95\% Cl) & $\begin{array}{l}50 / 53(94.3) \\
(84.6-98.1)\end{array}$ & & \\
\hline & NPA: n/N (\%) (95\% Cl) & $\begin{array}{l}117 / 119(98.3) \\
(94.1-99.5)\end{array}$ & & \\
\hline & OPA: n/N (\%) (95\% Cl) & $\begin{array}{l}\text { 167/172 (97.1) } \\
(93.4-98.8)\end{array}$ & & \\
\hline & Kappa coefficient (95\% Cl) & $0.93(0.87-0.99)$ & & \\
\hline \multirow[t]{7}{*}{ Reader C } & Positive & 52 & 3 & 55 \\
\hline & Negative & 2 & 116 & 118 \\
\hline & Total & 54 & 119 & 173 \\
\hline & PPA: n/N (\%) (95\% Cl) & $\begin{array}{l}52 / 54(96.3) \\
(87.5-99.0)\end{array}$ & & \\
\hline & NPA: n/N (\%) (95\% Cl) & $\begin{array}{l}116 / 119(97.5) \\
(92.8-99.1) \\
\end{array}$ & & \\
\hline & OPA: n/N (\%) (95\% Cl) & $\begin{array}{l}168 / 173(97.1) \\
(93.4-98.8)\end{array}$ & & \\
\hline & Kappa coefficient $(95 \%$ Cl) & $0.93(0.88-0.99)$ & & \\
\hline
\end{tabular}

IHC: immunohistochemistry; BISH: brightfield in situ hybridization; PPA: positive percent agreement; NPA: negative percent agreement; OPA: overall percent agreement.

Note: IHC/BISH status: positive $=\mathrm{IHC}$ is positive or BISH is amplified negative $=\mathrm{IHC}$ is negative and $\mathrm{BISH}$ is non-amplified.

Table 8 Summary of inter-reader agreement analyses

\begin{tabular}{lllll}
\hline Assay & $\begin{array}{l}\text { Minimum } \\
\text { APA }\end{array}$ & $\begin{array}{l}\text { Maximum } \\
\text { APA }\end{array}$ & $\begin{array}{l}\text { Minimum } \\
\text { ANA }\end{array}$ & $\begin{array}{l}\text { Maximum } \\
\text { ANA }\end{array}$ \\
\hline $\begin{array}{l}\text { Gene-protein } \\
\text { IHC }\end{array}$ & $95.2 \%$ & $97.2 \%$ & $98.1 \%$ & $98.8 \%$ \\
\hline Single IHC & $92.2 \%$ & $96.2 \%$ & $97.0 \%$ & $98.5 \%$ \\
\hline $\begin{array}{l}\text { Gene-protein } \\
\text { BISH }\end{array}$ & $93.5 \%$ & $97.9 \%$ & $97.7 \%$ & $99.2 \%$ \\
\hline Single BISH & $88.2 \%$ & $93.8 \%$ & $95.5 \%$ & $97.5 \%$ \\
\hline $\begin{array}{l}\text { Gene-protein } \\
\text { IHC/BISH }\end{array}$ & $91.7 \%$ & $95.2 \%$ & $96.4 \%$ & $98.0 \%$ \\
\hline \begin{tabular}{l} 
Single IHC/BISH 89.7\% \\
\hline APA: average p0sivive
\end{tabular} & $94.3 \%$ & $95.2 \%$ & $97.3 \%$ \\
\hline
\end{tabular}

$A P A$ : average positive agreement; ANA: average negative agreement; IHC: immunohistochemistry; $B I S H$ : brightfield in situ hybridization.
Table 9 Inter-reader agreement by reader pair and assay

\begin{tabular}{|c|c|c|c|}
\hline Reader Pair & Assay & APA & ANA \\
\hline \multirow[t]{6}{*}{ A vs. B } & Gene-protein IHC & 96.1 & 98.5 \\
\hline & Single $I H C$ & 93.9 & 97.8 \\
\hline & Gene-protein BISH & 97.9 & 99.2 \\
\hline & Single BISH & 93.8 & 97.5 \\
\hline & Gene-protein IHC/BISH & 95.2 & 98.0 \\
\hline & Single $I H C / B I S H$ & 93.3 & 96.9 \\
\hline \multirow[t]{6}{*}{ A vs. C } & Gene-protein IHC & 97.2 & 98.8 \\
\hline & Single $I H C$ & 96.2 & 98.5 \\
\hline & Gene-protein ISH & 93.5 & 97.7 \\
\hline & Single BISH & 92.1 & 97.0 \\
\hline & Gene-protein IHC/BISH & 94.4 & 97.6 \\
\hline & Single IHC/BISH & 94.3 & 97.3 \\
\hline \multirow[t]{6}{*}{ B vs. C } & Gene-protein IHC & 95.2 & 98.1 \\
\hline & Single $I H C$ & 92.2 & 97.0 \\
\hline & Gene-protein BISH & 93.8 & 97.7 \\
\hline & Single BISH & 88.2 & 95.5 \\
\hline & Gene-protein IHC/BISH & 91.7 & 96.4 \\
\hline & Single IHC/BISH & 89.7 & 95.2 \\
\hline
\end{tabular}

APA: average positive agreement; $A N A$ : average negative agreement; $I H C$ : immunohistochemistry; BISH: brightfield in situ hybridization.

breast cancer samples based on the quantitative reverse transcription-polymerase chain reaction (qRT-PCR) has been proposed, but has not been approved by the FDA. Based on a recent publication comparing the performance of HER2 qRT-PCR-based testing with that of the FDAapproved HER2 IHC and HER2 FISH methods [20], Ignatiadis and Sotirious have raised concerns about the use of HER2 qRT-PCR for clinical diagnostics [21]. The HER2 qRT-PCR method failed to detect equivocal cases and produced false negative results. Therefore, the need for a better assay to assess HER2 status in breast cancer, particularly in equivocal cases and in cases with tumor heterogeneity, remains.

With an incidence of approximately 4\%, HER2 false negative (IHC negative and FISH positive) and false positive (IHC positive and FISH negative) results cannot be ignored [1,17]. In one study, 9.7\% (174/1787) of breast cancer patients were HER2 false positive cases, but they still benefited from adjuvant trastuzumab therapy [22]. In another study, lapatinib therapy had significant positive effects in FISH positive breast cancer patients whose IHC tests had been $0,1+$, or $2+$ [13]. Thus, the detection of both false negative and false positive HER2 breast cancer cases is important.

HER2 IHC assays are effective methods for detecting tumor heterogeneity and equivocal cases based on HER2 protein staining under a light microscope, but these assays are semi-quantitative and subjective. Thus, additional quantitative gene analysis is required for equivocal cases 
using a HER2 ISH assay. HER2 false negative cases will be missed if only HER2 IHC is applied while HER2 false positive cases will be missed if only HER2 ISH method is utilized. Thus, the optimum HER2 testing protocol uses both HER2 IHC and HER2 ISH assays [23].

To overcome the weaknesses of current HER2 tests, we have successfully developed an automated brightfield tricolor gene-protein assay for the detection of HER2 protein, the HER2 gene, and CEN17. The novel aspect of the assay is the use of a blocker to prevent background staining caused by the binding of the DNP hapten of the HER2 probe to tissue sections after they have been processed through a DAB-based IHC assay. Although three research groups have previously reported the technical achievement of combining HER2 IHC and single color brightfield HER2 ISH to co-visualize HER2 protein and the HER2 gene on FFPE breast cancer tissue sections, all of these combined assays required several manual steps for the ISH procedure.

The HER2 gene-protein assay described herein is a significant improvement in the field because: 1) it demonstrates tricolor co-localization of the HER2 protein, HER2 gene, and CEN17 targets on well-preserved breast cancer tissue sections and 2) it automates the entire protocol of a gene-protein assay from deparaffinization to counterstaining. Extensive analyses of the findings of three pathologists with different levels of HER2 test scoring experience for the combination HER2 gene-protein assay relative to those of the single HER2 IHC and HER2 \& CEN17 BISH assays revealed excellent concordance. The statistical analysis suggests that the HER2 gene-protein assay is a robust and reliable assay and provides advantages over single HER2 IHC and HER2 \& CEN17 BISH assays.

Among the technical challenges we faced in developing the HER2 gene-protein assay was identifying an appropriate multicolor scheme. Previously, Downs-Kelly [7] and Ni et al. [8] used AP-based fast red staining of HER2 protein followed by HRP-based silver or DAB staining of HER2 gene, respectively. We evaluated APbased fast blue detection of HER2 IHC followed by the HER2 BISH assay to obtain a tricolor detection scheme in which HER2 protein was blue, the HER2 gene was black, and CEN17 was red (data not shown), but this scheme proved to be less than optimal; the pathologists had difficulty scoring weak HER2 IHC staining because the fast blue AP-based IHC staining was less crisp and because both fast blue and hematoxylin counterstain are blue. Therefore, because most pathologists are accustomed to scoring DAB-based IHC detection for HER2 protein, we investigated a detection scheme using a combination of conventional DAB-based detection of HER2 protein and BISH detection of HER2 and CEN17 targets. The sequence of HER2 IHC and HER2 \&
CEN17 BISH staining was also evaluated to optimize HER2 protein staining. As Reisenbichler et al. [9] previously noted, we observed weaker HER2 protein staining when the HER2 IHC portion of the assay was performed after the HER2 \& CEN17 BISH portion of the assay (data not shown). They compensated for the weaker HER2 IHC staining by increasing the anti-HER2 antibody incubation time from $30 \mathrm{~min}$ to $45 \mathrm{~min}$. In contrast, we determined that the HER2 IHC steps should be performed first to maintain HER2 IHC staining quality, particularly in cases with low expressed HER2 protein.

Reisenbichler et al. [9] also reported that they could not obtain HER2 CISH signals when the CISH assay was performed after HER2 IHC using DAB detection. We encountered a similar obstacle during the development of our HER2 gene-protein assay, but primarily for CEN17 BISH detection. We found that a longer protease digestion time or a higher protease concentration was required to obtain a consistent CEN17 BISH signal with difficult tissue samples to stain for CEN17 signals. As we have demonstrated in this report, our optimized HER2 \& CEN17 BISH assay provided successful visualization of the HER2 gene and CEN17 targets after DAB-based HER2 IHC.

Another major issue encountered during assay development was a high level of silver background staining from the silver-based HER2 BISH detection. The silver background staining was observed mainly in the nuclei and also some background staining was seen with $D A B$ staining. It did not occur when the DNP-labeled HER2 probe was omitted from the assay (data not shown). Also, omission of the DAB chromogen and hydrogen peroxide from the IHC procedure prevented silver background staining from silver-based HER2 BISH detection (data not shown). Therefore, we hypothesized that there was an interaction between $D A B$ and the DNP hapten and the BISH detection for the DNP hapten was responsible for the high levels of silver background staining. Because extra washing after the HER2 IHC did not eliminate the silver background staining (data not shown), we concluded that the DAB molecules were covalently bound to the nuclear DNA.

It is well established that $\mathrm{DAB}$ is a carcinogen and that carcinogenic agents bind to DNA. Oxidative intermediates of the $\mathrm{DAB}$ analogue benzidine have been shown to form covalent bonds to DNA, thereby localizing DAB in the cell nucleus [24,25]. During the development of the HER2 gene-protein assay, the DNP-labeled probes appeared to be binding to the peroxidase deposited DAB. The exact mechanism of this interaction is unknown, but electron-rich aromatic compounds (such as DAB) and electron-deficient aromatic compounds (such as DNP) are known to form aromatic pi-stacks and/or charge transfer complexes [26]. Therefore, we speculated that another aromatic molecule present in excess during hybridization would act as a 
competitor for this non-covalent attraction, analogous to the use of protein blockers in protein immunodetection to prevent non-specific protein binding. After testing several compounds with various electronic and aqueous solubility properties (data not shown), we identified naphthol phosphate as a suitable blocker for use during hybridization with DNP-labeled probes.

A HER2 gene-protein assay could be developed by combining two darkfield assays, namely HER2 fluorescence IHC and HER2 FISH assays. However, the current brightfield HER2 gene-protein assay offers several advantages over a darkfield gene-protein assay: 1 ) the ability to simultaneously observe the HER2 protein, HER2, and CEN17 targets in the context of tissue morphology; 2) the use of an established scoring system for DAB-based HER2 IHC assays; 3 ) the use of a regular light microscope for slide observations, negating the need for a darkroom; 4) full automation, which is optimal for reproducibility; and 5) permanent preservation of both the IHC and ISH signals. A HER2 gene-protein assay could also be developed using DAB-based HER2 IHC and HER2 FISH assays. This assay would have fewer disadvantages than the gene-protein assay using fluorescence $\mathrm{IHC}$, but would still require an expensive fluorescence microscope and a darkroom. In addition, long term preservation of the FISH signal would be difficult and no completely automated protocol would be available for this assay.

\section{Conclusions}

We have developed a robust automated procedure for the simultaneous visualization of HER2 protein, the HER2 gene, and CEN17 in FFPE xenograft tumor tissue sections and have demonstrated its accuracy in the analysis of FFPE breast cancer TMA slides. The successful multiplexing of two FDA-approved HER2 IHC and HER2 \& CEN17 BISH assays was achieved by the inclusion of naphthol phosphate in the hybridization buffer to eliminate the silver background staining resulting from the HER2 BISH detection. This HER2 gene-protein assay demonstrated the heterogeneity of HER2 protein expression in breast cancer cell populations and the simultaneous detection of HER2 protein, the HER2 gene, and CEN17 allowed differentiation of HER2 IHC 2+ cases to HER2 \& CEN17 BISH positive or negative. Furthermore, it correctly identified cases yielding false negatives in HER2 IHC tests as HER2 \& CEN17 BISH positive. This new method for brightfield tricolor detection of HER2 protein, the HER2 gene, and CEN17 might be useful in more accurately assessing the HER2 status of breast cancer patients, particularly in equivocal cases or cases with heterogeneous tumors. The HER2 geneprotein assay might also be useful in gastric cancer, which often exhibits tumor heterogeneity. Furthermore, this strategy for gene-protein detection assays could be applied to other cancer biomarkers, such as EGFR and met proto-oncogene.

\section{Abbreviations}

ANA: Average negative agreement; AP: Alkaline phosphatase; APA: Average positive agreement; ASCO: American Society of Clinical Oncology; BISH: Brightfield in situ hybridization; CAP: College of American Pathologists; CEN17: Chromosome 17 centromere; CISH: Chromogenic in situ hybridization; DAB: 3,3'-diaminobenzidine; DIG: Digoxigenin; DNP: 2,4dinitrophenyl; EGFR: Epidermal growth factor receptor; FDA: United States Food and Drug Administration; FFPE: Formalin-fixed paraffin-embedded; FISH: Fluorescence in situ hybridization; HER2: Human epidermal growth factor receptor 2; HRP: Horseradish peroxidase; IHC: Immunohistochemistry; ISH: In situ hybridization; NPA: Negative percent agreement; OPA: Overall percent agreement; PPA: Positive percent agreement; qRT-PCR: Quantitative reverse transcription-polymerase chain reaction; TMA: Tissue microarray.

\section{Competing interests}

HN, MP, BK, NW, PB, SS, IB, JRM, CB, and TM are employed by Ventana Medical Systems, Inc. HT received a grant in support of this research from Ventana Medical Systems, Inc.

\section{Authors' contributions}

HN and TMG developed the HER2 gene-protein assay, performed feasibility studies, stained the clinical samples, and prepared the manuscript draft and image data. BK, HN, CB, and TMG identified the blocker for HER2 geneprotein assay. Pathologists MP, NW, PB, SS, and HT consulted in assay development and/or scored samples for assay development and validation. IB and JRM conducted all statistical analyses. All authors provided intellectual input for the study and approved the final manuscript.

\section{Acknowledgments}

We would like to thank Vu Nguyen (Research and Development, Ventana Medical Systems, Inc.) for instrument maintenance and Kyle Kimble, J.D., Ph. D. (Legal Affairs, Ventana Medical Systems, Inc.) and Cynthia Carr, Ph.D. (Clinical Affairs, Ventana Medical Systems, Inc.) for their critical reviews of the manuscript. Professional editing services were provided by Lauren B. Murata, Ph.D. (Clinical Affairs, Ventana Medical Systems, Inc.).

\section{Author details}

${ }^{1}$ Medical Innovation, Ventana Medical Systems, Inc., Tucson, AZ, USA. ${ }^{2}$ Technology and Applied Research, Ventana Medical Systems, Inc., Tucson, AZ, USA. ${ }^{3}$ Roche Tissue Diagnostics, Roche Diagnostics S.L., Barcelona, Spain. ${ }^{4}$ Scientific Affairs, Ventana Medical Systems, Inc., Tucson, AZ, USA. ${ }^{5}$ Medical Affairs, Ventana Medical Systems, Inc., Tucson, AZ, USA. ${ }^{6}$ Biostatistics and Data Management, Ventana Medical Systems, Inc., Tucson, AZ, USA.

${ }^{7}$ Department of Pathology, National Cancer Center Hospital, Tokyo, Japan.

Received: 31 March 2012 Accepted: 13 May 2012

Published: 30 May 2012

\section{References}

1. Lee JA, Shaheen M, Walke T, Daly M: Clinical and health economic outcomes of alternative HER2 test strategies for guiding adjuvant trastuzumab therapy. Expert Rev Pharmacoecon Outcome Res 2011, 11:325-341.

2. Wolff AC, Hammond ME, Schwartz JN, Hagerty KL, Allred DC, Cote RJ, Dowsett M, Fitzgibbons PL, Hanna WM, Langer A, McShane LM, Paik S, Pegram MD, Perez EA, Press MF, Rhodes A, Sturgeon C, Taube SE, Tubbs R, Vance GH, van de Vijver M, Wheeler TM, Hayes DF: American Society of Clinical Oncology/College of American Pathologists guideline recommendations for human epidermal growth factor receptor 2 testing in breast cancer. J Clin Oncol 2007, 25:118-145.

3. Madrid MA, Lo RW: Chromogenic in situ hybridization (CISH): a novel alternative in screening archival breast cancer tissue samples for HER22/neu status. Breast Cancer Res 2004, 6:R593-R600.

4. Sauter G, Lee J, Barlett JMS, Slamon DJ, Press MF: Guidelines for human epidermal growth factor receptor 2 testing: biologic and methodologic considerations. J Clin Oncol 2009, 27:1324-1333.

5. Shah S, Chen B: Testing for HER2 in breast cancer: a continuing evolution. Patholog Res Int 2011, 2011:903202. 
6. Dowsett M, Hanby AM, Laing R, Walker R: HER2 testing in the UK: consensus from a national consultation. J Clin Pathol 2007, 60:685-689.

7. Downs-Kelly E, Pettay J, Hicks D, Skacel M, Yoder B, Rybicki L, Myles J, Sreenan J, Roche P, Powell R, Hainfeld J, Grogan T, Tubbs R: Analytical validation and interobserver reproducibility of EnzMet GenePro: a second-generation bright-field metallography assay for concomitant detection of HER2 gene status and protein expression in invasive carcinoma of the breast. Am J Surg Pathol 2005, 29:1505-1511.

8. Ni R, Mulligan AM, Have C, O'Malley FP: PGDS, a novel technique combining chromogenic in situ hybridization and immunohistochemistry for the assessment of ErbB2 (HER2/neu) status in breast cancer. Appl Immunohistochem Mol Morphol 2007, 15:316-324.

9. Reisenbichler ES, Horton D, Rasco M, Andea A, Hameed O: Evaluation of dual immunohistochemistry and chromogenic in situ hybridization for HER2 on a single section. Am J Clin Pathol 2012, 137:102-110.

10. Bunn PA Jr, Helfrich B, Soriano AF, Franklin WA, Varella-Garcia M, Hirsch FR, Baron A, Zeng C, Chan DC: Expression of HER-2/neu in human lung cancer cell lines by immunohistochemistry and fluorescence in situ hybridization and its relationship to in vitro cytotoxicity by trastuzumab and chemotherapeutic agents. Clin Cancer Res 2001, 7:3239-3250.

11. Cicchetti DV, Feinstein AR: High agreement but low kappa: II. Resolving the paradoxes. J Clin Epidemiol 1990, 43:551-558.

12. RosS JS: Point: fluorescence in situ hybridization is the preferred approach over immunohistochemistry for determining HER2 status. Clin Chem 2011, 57:980-982.

13. Press MF, Finn RS, Cameron D, Di Leo A, Geyer CE, Villalobos IE, Santiago A, Guzman R, Gasparyan A, Ma Y, Danenberg K, Martin AM, Williams L, Oliva C, Stein S, Gagnon R, Arbushites M, Koehler MT: HER-2 gene amplification, HER-2 and epidermal growth factor receptor mRNA and protein expression, and Lapatinib efficacy in women with metastatic breast cancer. Clin Cancer Res 2008, 14:7861-7870.

14. Tapia C, Schrmal P, Simon R, Al-Kuraya KS, Maurer R, Mirlacher M, Novotny H, Spichtin H, Mihatsch MJ, Sauter G: HER2 analysis in breast cancer: reduced immunereactivity in FISH non-informative cancer biopsies. Int J Oncol 2004 25:1551-1557

15. Nakhleh RE, Grimm EE, Idowu MO, Souers RJ, Fitzgibbons PL: Laboratory compliance with the American Society of Clinical Oncology/College of American Pathologists guidelines for human epidermal growth factor receptor 2 testing. Arch Pathol Lab Med 2010, 134:728-734.

16. Zarbo RJ, Hammond ME: Conference summary, Strategic Science symposium: Her-2/neu testing of breast cancer patients in clinical practice. Arch Pathol Lab Med 2003, 127:549-553.

17. Bernasconi B, Chiaravalli AM, Finzi G, Milani K, Tibiletti MG: Genetic heterogeneity in HER2 testing may influence therapy eligibility. Breast Cancer Res Treat 2012, 133:161-168.

18. Vance GH, Barry TS, Bloom KJ, Fitzgibbons PL, Hicks DG, Jenkins RB, Persons DL, Tubbs RR, Hammond EH: Genetic heterogeneity in HER2 testing in breast cancer: panel summary and guidelines. Arch Pathol Lab Med 2009, 133:611-612.

19. Nitta H, Hauss-Wegrzyniak B, Lehrkamp M, Murillo AE, Gaire F, Farrell M, Walk E, Penault-Llorca F, Kurosumi M, Dietel M, Wang L, Loftus M, Pettay J, Tubbs RR, Grogan TM: Development of automated brightfield double in situ hybridization (BDISH) application for HER2 gene and chromosome 17 centromere (CEN 17) for breast carcinoma and an assay performance comparison to manual dual color HER2 fluorescence in situ hybridization (FISH). Diagn Pathol 2008, 3:41.

20. Dabbs DJ, Klein ME, Mohsin SK, Tubbs RR, Shuai Y, Bhargava R: High falsenegative rate of HER2 quantitative reverse transcription polymerase chain reaction of the Oncotype DX test: an independent quality assurance study. J Clin Oncol 2011, 29:4279-4285.

21. Ignatiadis M, Sotiriou C: Should we assess HER2 status by Oncotype DX ${ }^{\circledR}$ ? Nature 2012, 9:12-14.

22. Paik S, Kim C, Wolmark N: HER2 status and benefit from adjuvant trastuzumab in breast cancer. N Engl J Med 2008, 358:1409-1411.

23. Arena V, Pennacchia I, Carbone A, Capelli A: Fluorescent in situ hybridization for human epidermal growth factor receptor 2 assessment in breast cancer: is it applicable as a primary test? J Clin Oncol 2009, 27:e8.

24. Yamazoe $Y$, Roth RW, Kadlubar FF: Reactivity of benzidine diimine with DNA to form N-(deoxyguanosin-8-yl)-benzidine. Carcinogensis 1986, 7:179-182.
25. Gimmler-Luz MC, de Andrade HHR, Marafon AT: Benzidine- and diaminobenzidine-induced micronuclei in mice after intraperitoneal and oral single or multiple treatment. Brazilian J Gen 1997, 20:247-252.

26. Saito G, Matsunaga Y: Charge transfer and proton-transfer in the formation of molecular complexes. VIII. Benzidine-2,4-dinitophenol complexes. Bull Chem Soc Jpn 1974, 47:1020-1021.

doi:10.1186/1746-1596-7-60

Cite this article as: Nitta et al:: A gene-protein assay for human epidermal growth factor receptor 2 (HER2): brightfield tricolor visualization of HER2 protein, the HER2 gene, and chromosome 17 centromere (CEN17) in formalin-fixed, paraffin-embedded breast cancer tissue sections. Diagnostic Pathology 2012 7:60.

\section{Submit your next manuscript to BioMed Central and take full advantage of:}

- Convenient online submission

- Thorough peer review

- No space constraints or color figure charges

- Immediate publication on acceptance

- Inclusion in PubMed, CAS, Scopus and Google Scholar

- Research which is freely available for redistribution 